\title{
Estimation of cognitive and affective disorders occurrence in patients with Lyme borreliosis
}

\author{
Barbara Oczko-Grzesik1', Lucjan Kępa', Monika Puszcz-Matlińska², Robert Pudlo³, Anna Żurek², \\ Teresa Badura-Głąbik² \\ ${ }^{1}$ Clinical Department of Infectious Diseases, Bytom, Medical University of Silesia, Katowice, Poland \\ ${ }^{2}$ Department of Infectious Diseases, Specialistic Hospital No 1, Bytom, Poland \\ ${ }^{3}$ Clinical Department of Psychiatry, Tarnowskie Góry, Medical University of Silesia, Katowice, Poland \\ Oczko-Grzesik B, Kępa L, Puszcz-Matlińska M, Pudlo R, Żurek A, Badura-Głąbik T. Estimation of cognitive and affective disorders occurrence \\ in patients with Lyme borreliosis. Ann Agric Environ Med. 2017; 24(1): 33-38. doi: 10.5604/12321966.1229002
}

\begin{abstract}
Introduction and objective. Lyme borreliosis (LB) is a disease caused by the bacteria Borrelia burgdorferi. The most common symptoms are related to the skin, musculo-scelatal system, central and peripheral nervous system, rarely to the heart muscle and the eye, and may occur in the multistage course of the disease. LB may additionally be accompanied by psychopathological symptoms. The aim of the study is estimation of the cognitive and affective disorders occurence in patients with LB.

Material and methods. The study was carried out in the group of 121 patients (61 females, 60 males) aged 18-65; mean age 46 years. All patients were diagnosed with late-stage of LB: 46 patients (38\%) with Lyme arthritis and 75 patients (62\%) with neuroborreliosis. Evaluation of the cognitive and affective functioning of patients was performed on the basis of a standardized interview and test methods: the Mini-Mental State Examination (MMSE), Clock Drawing Test (CDT) and the Beck Depression Inventory (BDI).

Results. Cognitive disorders occurred statistically significantly more often in patients with neuroborreliosis (14.7\%) than in patients with Lyme arthritis (4.3\%). A group of females with neuroborreliosis and a group of males with the same diagnosis demonstrated cognitive deficits significantly more often ( $23.3 \%$ and $8.9 \%$, respectively), compared to groups of patients with Lyme arthritis (6.5\% in females and no cognitive deficits in males). A significantly higher percentage of depressive disorders was also noted in the group of males and females with neuroborreliosis (50.7\%), compared to the group of patients with Lyme arthritis (39.1\%). The symptoms of depression were particularly frequent in the females with neuroborreliosis (60\%). The severity of depression measured by BDI was mild or moderate in most cases. In the examined groups, more patients with neuroborreliosis (44\%), both in females (36.7\%) and males (48.9\%), demonstrated anxiety disorders. The obtained results showed a higher frequency of affective disorders compared to cognitive deficits, both in patients with Lyme arthritis and neuroborreliosis.

Conclusions. An increased frequency of depressive and neurotic disorders was observed in patients with LB, particularly in patients with neuroborreliosis. Neurotic disorders, mainly adaptive, were most common in males with LB, while depressive disorders were more frequent in females. An increased frequency of cognitive deficits was observed in patients with neuroborreliosis, particularly in females.
\end{abstract}

\section{Key words}

Lyme borreliosis, neuroborreliosis, cognitive disorders, affective disorders, depression

\section{INTRODUCTION}

Lyme borreliosis (LB) is an infectious disease caused by the bacteria Borrelia burgdorferi (B.b.) of the spirochetes genus. It is transmitted by the bite of ticks belonging to the genus Ixodes. The natural reservoirs of B.b., apart from all stages of development of these arthropods, are mainly wild animals (small rodents, deer, birds); however, livestock and pets may also become infected. This spirochetosis is found in the northern hemisphere. People occupationally exposed to tick bite, i.e. foresters, other forestry workers and agricultural workers are at particular risk of getting LB. A non-occupational exposure to Borrelia burgdorferi is connected with recreation in parks and forests, hiking, working in gardens, and is an important environmental risk factor. LB was declared a reportable disease in Poland

Address for correspondence: Barbara Oczko-Grzesik, Clinical Department of Infectious Diseases, Bytom, Medical University of Silesia, Katowice, Poland E-mail: bgrzesik@hoga.pl

Received: 29 September 2013; accepted: 17 April 2014; first published on December, 2016 in 1996. In subsequent years, an increasing number of cases were registered - from 655 cases in 1997 to 10,329 in 2009, which resulted also from better diagnostic possibilities. In 2010, no increasing trend was seen in Poland for the first time [1].

LB is a multisystemic, multistage disease with a variety of possible constellations of symptoms related to the skin, musculo-sceletal system, central as well as peripheral nervous system, and less often to the heart muscle and the eye. The most characteristic skin symptom is erythema migrans (EM), which appears in the early localized stage. It occurs after a few to 30 days (sometimes even up to 3 months) after the tick bite in $50-70 \%$ of the infected persons as an expanding erythema at the site of the tick bite. Classically, the central part clears after a few days and the border expands peripherally. A spontaneous disappearance of EM is not equivalent to the eradication of the infection $[2,3]$.

Apart from the above manifestations, LB may be accompanied by psychopathological symptoms which are usually associated to mild encephalopathy or symptomatic neuroborreliosis $[4,5,6]$. 
Affective and cognitive disorders associated with somatic diseases tend to be described as a psychological reaction to stress resulting from the disease, as one of the symptoms or as a complication of the disease. In the latter case, there is a biological connection between the somatic and psychological condition. Obviously, psychopathological symptoms do not have to result from the somatic condition, sometimes psychological and somatic disorders have common elements of pathogenesis, e.g. depression and anxiety in cardiovascular diseases $[7,8]$.

Depression is one of the most common mental disorders nowadays and it is a frequent cause of hospitalization for patients over 50 years old. The population of people demonstrating symptoms of depression reaches 100 million a year. The prevalence of anxiety disorders, which are also among the most frequent mental disorders, is estimated to be at a similar level $[9,10]$.

The Polish data show that the number of patients requiring treatment due to affective disorders in 2001 was 484.4 per 100,000 in outpatient clinics and 57.1 per 100,000 population in hospitals [10]. However, it should be remembered that the comparison of epidemiological data from different studies is not completely reliable due to various diagnostic criteria for depression.

Most patients with depression (even up to 95\%) demonstrate anxiety symptoms. There are 3 types of relationship between anxiety and depression: the anxiety may be a symptom of depression, depressive and anxiety disorders may coexist (comorbidity), or the depression may be secondary to anxiety disorders. The latest option is usually used in the context of generalized anxiety disorder. The comorbidity of anxiety and depression is a negative prognostic factor and it may have a negative impact on compliance, increase the frequency of recurrence and the risk of drug resistance [11].

The development of anxiety and depressive disorders associated with somatic diseases may be interpreted as an unsuccessful adaptation to stress. The illness, particularly if it results in a long treatment process, the pain and deterioration of fitness, financial situation and necessity of changing social roles, requires a maximal use of the adaptive capacity, which may entail the appearance of mental disorders in some people [12].

Research to-date emphasizes particularly the co-existence of pain and depression. In the study by Corruble et al., $92 \%$ of patients complained of one and $76 \%$ of patients of more than one symptom of pain [13]. The most frequent pain complaints are headaches, lower back pain and arthralgia. The studies show that in patients experiencing pain, other symptoms like sleep disorders, decreased appetite, fatigue, memory and attention disorders and negative mood appear $[13,14]$.

Cognitive deficits may coexist with depressive disorders. In the literature, direct and short-term memory impairment, attention disorders, slowed thought processes and executive function impairment, including working memory efficiency, are emphasized $[9,15,16]$.

'Cognition' may be interpreted as a group of functions including the ability of humans to orientate themselves, gain information about themselves and the world, as well as the working memory, visual and verbal memory, attention, deduction, problem solving and social functioning ability $[9,17]$.

Cognitive deficits objectively observed and subjectively experienced in patients have a significant impact on their quality of life. They often affect their personal, social and professional life. The level of cognitive functioning may be influenced not only by certain diseases, including emotional disorders, but also by such variables as age, level of education, sense of well-being during examination, or experienced pain [18].

The study was inspired by observations of patients with both borreliosis and neuroborreliosis who often reported many complaints, such as deterioration of psychical wellbeing including negative mood, recurrent anxiety, less efficient mnemonic processes and attention.

\section{OBJECTIVE}

The aim of the study was analysis of the selected aspects of functioning in patients with borreliosis and neuroborreliosis in relation to the frequency of the occurrence of cognitive deficits, as well as depressive and anxiety disorders, particularly associated with stress, i.e. adaptive disorders and situational reactions.

\section{MATERIALS AND METHOD}

The study was carried out in patients hospitalized at the Department of Infectious Diseases, Specialistic Hospital No 1 in Bytom, Poland, between 2005-2012. The LB and neuroborreliosis was diagnosed in all patients on the basis of a standardized interview, physical examination and the results of laboratory tests, according to the current criteria [2, 3]. Serological tests were performed using the enzyme-linked immunosorbent assay (ELISA) and confirmed using western blotting. Neuroborreliosis was diagnosed on the basis of the cerebrospinal fluid test and proving intrathecal synthesis of anti-Borrelia burgdorferi antibodies.

A total of 121 patients (61 females, 60 males) aged 1865 , mean age 46 years, were enrolled into the study. All patients were diagnosed with late-stage LB (mean duration of infection -2.5 years): 46 patients (38\%) with Lyme arthritis and 75 patients (62\%) with neuroborreliosis. The group of patients with Lyme arthritis consisted of 31 females and 15 males, and the group with neuroborreliosis consisted of 30 females and 45 males. The groups were comparable in terms of age.

Patients with severe chronic somatic diseases (mainly cardiovascular, metabolic and degenerative diseases) and with severe mental illnesses diagnosed prior to the known or probable infection with Borrelia burgdorferi, which could significantly affect the results of the analysis, were excluded from the study. The majority of them were patients with Lyme arthritis. All individuals were tested prior to antibiotic therapy. Evaluation of the cognitive and emotional functioning of patients was performed on the basis of a standardized interview and test methods, such as MiniMental State Examination (MMSE), the Clock Drawing Test (CDT) and the Beck Depression Inventory (BDI).

Each patient underwent a standardized interview which included questions concerning past and current wellbeing, deterioration of mood, sleep disorders, decreased appetite, panic attacks and general anxiety with fear about the future (particularly about the health condition). The patients were also asked to subjectively evaluate the level of 
cognitive functioning, mainly memory and attention. ICD-10 diagnostic criteria were used for evaluation of the frequency of the occurrence of neurotic disorders (adaptive disorders and situational reactions in particular) [19].

The MMSE scale is a screening test which serves for the general assessment of cognitive functioning. It includes, among others, a brief assessment of orientation, direct and long-term memory, attention, calculation, naming, repetition and complex commands [20,21].

The Clock Drawing Test (CDT) checks cognitive and executive functions (particularly visual-spatial ability, planning and abstract thinking) using visual-spatial tasks. There are many different ways to evaluate CDT, both qualitative and quantitative. In the presented study, the Shulman scoring system was used [22]. Evaluation of cognitive functions was performed on the basis of the results of MMSE and CDT. Screening for depression was performed using BDI, which is a universally recognized screening tool [23].

All patients with abnormal test results were provided with psychoeducation and informed about further actions.

In the case of abnormalities, the test results were consulted at the Clinical Department of Psychiatry in Tarnowskie Góry, Medical University of Silesia, Katowice. The presented psychological tests were performed after receiving a patient's consent, and formed a part of routine diagnostics of $\mathrm{LB}$ late stage.

The obtained results were analyzed statistically by calculating mean values $(\widehat{\mathrm{x}})$ and the percentage $(\%)$. The statistical significance of the differences between analysed groups was evaluated using Student's t-test for independent groups. The results were considered significant at $\mathrm{p}<0.05$.

\section{RESULTS}

In the examined group, cognitive disorders occurred statistically significantly more often in patients with neuroborreliosis (14.7\%) than in patients with Lyme arthritis $(4,3 \%)$ (Table 1$)$. In some patients, various types of disorders coexisted. The difference is particularly evident when data are analysed separately by gender - the group of females with neuroborreliosis and the group of males with the same diagnosis demonstrated cognitive deficits significantly more often $(23.3 \%$ and $8.9 \%$, respectively), compared to groups of patients with Lyme arthritis $(6.5 \%$ in females and no cognitive deficits in males) (Tab. 2).

Table 1. Frequency of cognitive and/or depressive and/or anxiety disorders occurence in patients with Lyme arthritis or neuroborreliosis

\begin{tabular}{|c|c|c|}
\hline & $\begin{array}{l}\text { Patients with } \\
\text { Lyme arthritis }\end{array}$ & $\begin{array}{c}\text { Patients with } \\
\text { neuroborreliosis }\end{array}$ \\
\hline$\%(n)$ & $100 \%(46)$ & $100 \%(75)$ \\
\hline \multirow{2}{*}{ Cognitive disorders } & $4.3 \%(2)$ & $14.7 \%(11)$ \\
\hline & \multicolumn{2}{|c|}{$p<0.05$} \\
\hline \multirow{2}{*}{ Depressive disorders } & $39.1 \%(18)$ & $50.7 \%(38)$ \\
\hline & \multicolumn{2}{|c|}{ NSD } \\
\hline \multirow{2}{*}{ Anxiety disorders } & $32.6 \%(15)$ & $44 \%(33)$ \\
\hline & \multicolumn{2}{|c|}{ NSD } \\
\hline \multirow{2}{*}{ Patients without disorders } & $30.4 \%(14)$ & $18.7 \%(14)$ \\
\hline & \multicolumn{2}{|c|}{ NSD } \\
\hline
\end{tabular}

NSD - no statistically significant difference
Table 2. Frequency of cognitive and/or depressive and/or anxiety disorders occurrence in women and men with Lyme arthritis or neuroborreliosis

\begin{tabular}{|c|c|c|c|c|}
\hline & $\begin{array}{l}\text { Females with } \\
\text { Lyme arthritis }\end{array}$ & $\begin{array}{l}\text { Females with } \\
\text { neuroborreliosis }\end{array}$ & $\begin{array}{c}\text { Males with } \\
\text { Lyme arthritis }\end{array}$ & $\begin{array}{c}\text { Males with } \\
\text { neuroborreliosis }\end{array}$ \\
\hline$\%(n)$ & $100 \%(31)$ & $100 \%(30)$ & $100 \%(15)$ & $100 \%(45)$ \\
\hline \multirow[t]{2}{*}{$\begin{array}{l}\text { Cognitive } \\
\text { disorders }\end{array}$} & $6.5 \%(2)$ & $23.3 \%(7)$ & $0 \%(0)$ & $8.9 \%(4)$ \\
\hline & \multicolumn{2}{|c|}{$p<0.01$} & \multicolumn{2}{|c|}{ NSD } \\
\hline \multirow[t]{2}{*}{$\begin{array}{l}\text { Depressive } \\
\text { disorders }\end{array}$} & $41.9 \%$ (13) & $60 \%(18)$ & $33.3 \%(5)$ & $44.4 \%(20)$ \\
\hline & \multicolumn{2}{|c|}{ NSD } & \multicolumn{2}{|c|}{ NSD } \\
\hline
\end{tabular}

\begin{tabular}{lcccc}
\hline $\begin{array}{l}\text { Anxiety } \\
\text { disorders }\end{array}$ & $29 \%(9)$ & $36.7 \%(11)$ & $40 \%(6)$ & $48.9 \%(22)$ \\
\hline \multicolumn{3}{c}{ NSD } & NSD \\
\hline $\begin{array}{l}\text { Patients } \\
\text { without } \\
\text { disorders }\end{array}$ & $32.3 \%(10)$ & $10 \%(3)$ & $26.7 \%(4)$ & $24.4 \%(11)$ \\
\hline \multicolumn{5}{c}{ NSD } \\
\hline
\end{tabular}

NSD - no statistically significant difference

A significantly higher percentage of depressive disorders was also noted in the group of males and females with neuroborreliosis (50.7\%), compared to the group of patients with Lyme arthritis (39.1\%) (Tab. 1). The symptoms of depression were particularly frequent in the females with neuroborreliosis (60\%). In the group of males with neuroborreliosis, depressive disorders were also more frequent than in the group of males with Lyme arthritis, but the difference was not as significant as in the females (Tab. 2). The severity of depression measured by BDI was mild or moderate in most cases (Tab. 3).

In the examined group, more patients with neuroborreliosis (ca. 44\%), both in females (36.7\%) and males (48.9\%), demonstrated anxiety disorders (Tab. 1,2).

One-third of all patients with Lyme arthritis (30.4\%) showed no cognitive abnormalities or emotional disorders. In the group of patients with neuroborreliosis, only onefifth did not show any deficits (18.7\%) (Tab. 1). Cognitive or emotional disorders were particularly frequent in females with neuroborreliosis, in whom no abnormalities were found in only in $10 \%$ (Tab. 2).

The obtained results showed a higher frequency of affective disorders compared to cognitive deficits, both in patients with Lyme arthritis and neuroborreliosis (Tab. 1).

\section{DISCUSSION}

The mechanism of the occurrence of neuropsychological deficits and psychopathological symptoms associated with LB and neuroborreliosis has not as yet been completely explained. They are considered to be connected with immunological, toxic and metabolic processes which take place in the involved system $[24,25,26]$.

Diagnosing of LB or neuroborreliosis is a long-lasting process for many patients suffering from physical complaints; it also involves troublesome medical procedures. Diagnosis of neuroborreliosis usually entails more serious consequences than in the case of Lyme arthritis. Treatment schedules of LB involve antibiotic therapy for a few weeks $[27,28,29$, 
Table 3. Severity of depression according to BDI in males and females with Lyme arthritis or neuroborreliosis

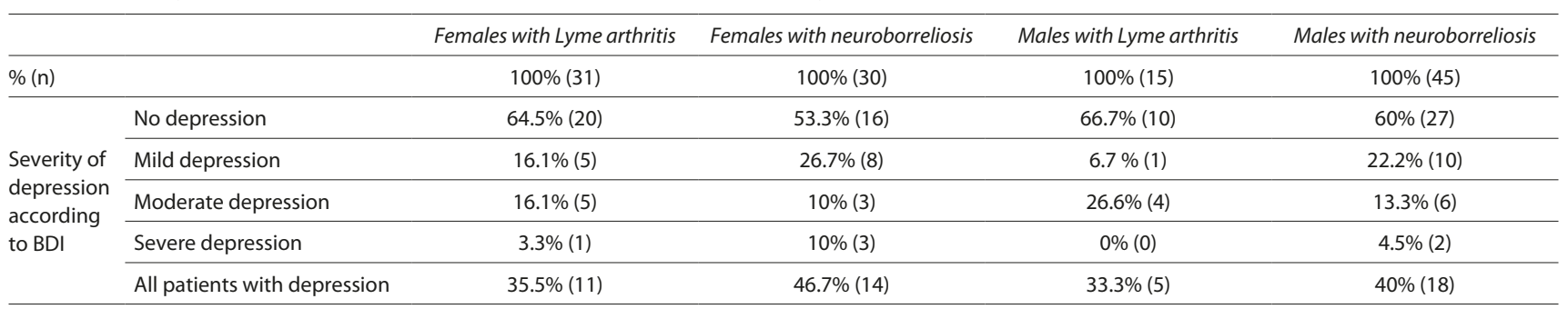

Table 4. Mean point values $(\widehat{x})$ obtained in psychological tests by patients with LB

\begin{tabular}{lccccc}
\hline & $\begin{array}{c}\text { Patients with } \\
\text { Lyme arthritis }\end{array}$ & $\begin{array}{c}\text { Patients with } \\
\text { neuroborreliosis }\end{array}$ & $\begin{array}{c}\text { Females with } \\
\text { Lyme arthritis }\end{array}$ & $\begin{array}{c}\text { Females with } \\
\text { neuroborreliosis }\end{array}$ & $\begin{array}{c}\text { Males with } \\
\text { Lyme arthritis }\end{array}$ \\
\hline MMSE & 28.58 & 28.33 & 28.64 & 28.2 & 28.46 \\
\hline CDT & 0.06 & 0.17 & 0.09 & 0.26 & 0 \\
\hline BDI & 10.26 & 11.62 & 10.06 & 13.26 & 10.11 \\
\hline
\end{tabular}

30, 31], and as a result, some patients might demonstrate reactive symptoms associated with the disease itself, as well as the duration and monotony of treatment [32, 33, 34]. Mild depressive or anxiety disorders interpreted as situational reactions (often with depressive mood) are among the most frequent abnormalities, which was also proved by the presented study. Similar observations were made by American researchers who noted depressive disorders and general anxiety disorder (GAD) in $49 \%$ of patients with LB [35].

Studies concerning comorbidity of LB or neuroborreliosis and affective disorders and cognitive deficits are relatively uncommon in the literature and some of them include case studies. Ogłodek et al. described mental disorders with depression as a main symptom in a patient with comorbidity of LB and psoriasis [36]. Another case concerned LB with cardiac manifestations: a patient demonstrated depressive disorders along with emotional lability, memory and attention deficits. After treatment, the cardiac manifestations disappeared, while mental disorders only improved [37]. Helon et al. described a patient with neuroborreliosis with disorders of consciousness, psychomotor agitation, behavioural disorders with aggression, and depressive disorders [38].

The presented study showed that patients with neuroborreliosis are at the highest risk of depressive, anxiety or cognitive disorders. Women in particular are susceptible to depressive disorders. Gender bias in chronic Lyme disease was presented by Stricker et al. [39], while Gustaw et al. analyzed a group of 33 patients in the early, acute stage of neuroborreliosis. Mild depressive disorders were observed in $50 \%$ of the patients, and deterioration of memory functions and mental processes in more than 21\% [40]. The analysis by Czupryna et al. concerning patients with neuroborreliosis, mainly in the late stage, showed symptoms of depression in nearly $37 \%$ of patients, attention disorders in $30 \%$ and memory disorders in almost $29 \%$ of patients [41]. The patients in the late stage of LB also constituted the majority of patients with various mental disorders associated with LB, including affective and cognitive disorders, described by Rudnik et al. [42].

The frequency of depressive and anxiety disorders demonstrated by presented patients corresponds with the data found in the literature, which prove that the more they are exposed to diseases with a high level of pain and long-term hospitalization, the more often they complain of deterioration of psychomotor functioning. The most frequent complaints include negative mood, anhedonia, the feeling of helplessness and hopelessness, irritability and fear about the future (particularly about the health condition). Blanc et al. pay attention to psychopathological symptoms other than depressive disorders and manic episodes, such as paranoid, catatonic and schizophrenic symptoms, hallucinations, aggression, panic attacks and obsessivecompulsive disorders which may occur in patients with LB or neuroborreliosis [43].

Cognitive functioning impairment in patients with LB, in particular those with neuroborreliosis, may be interpreted as a natural course of the infection of the nervous system. However, it should be emphasized that direct, short-term and working memory deficits and attention disorders which are observed in different groups of patients usually coexist with mood and anxiety disorders. As a result, it may be assumed that a part of cognitive disorders found in the examined patients belongs to the clinical picture of depression or anxiety disorders. This hypothesis entails vital therapeutic and prognostic implications. Westervelt et al. emphasize that neuropsychological deficits occur both in patients with neuroborreliosis confirmed by laboratory tests and imaging studies, and also in patients with no abnormalities in the above tests [44]. In the current study $30.4 \%$ of patients with Lyme arthritis and $18.7 \%$ with neuroborreliosis showed no cognitive or affective disorders. Juchnowicz et al. analyzed the occurrence of mental disorders in patients with Lyme arthritis and neuroborreliosis prior to antibiotic therapy and 6 months after the end of the therapy. The results of the study were very interesting: prior to the therapy, depression was found in 15.6 and $5 \%$ of patients, anxiety disorders in 5.2 and $5 \%$, and mild cognitive disorders in 37.7 and $55 \%$ of patients, respectively. These values decreased after therapy. In the group of patients with Lyme arthritis only $10.4 \%$ of the patients did not show any mental disorders, while all patients with neuroborreliosis demonstrated some abnormalities. In both groups, a significant increase in organic mood disorders was observed at 6 months after the end of therapy: from $14.3-75.3 \%$ and from $25-80 \%$ in patients with Lyme arthritis and neuroborreliosis, respectively. These changes may result 
from both mild encephalopathy and infection of the nervous system associated with LB [45].

The presented study is a contribution to the further analysis of the occurrence of cognitive, depressive and anxiety disorders in patients with LB and neuroborreliosis. The next step should involve applying more advanced tests for the evaluation of cognitive disorders than the screening tests used in this study, the selection of methods which will enable selective focusing on cognitive deficits. Also, the hypothesis assuming better social awareness of LB acquired over time and its impact on the occurrence of depressive and anxiety disorders in patients with LB should be verified.

The obtained results suggest the necessity of taking into account the possibility of the occurrence of mental disorders in diagnostics and therapy of LB.

An attempt of treatment is the natural consequence of epidemiological studies. The evaluation of the influence of antidepressant or anti-anxiety treatment on cognitive disorders is currently planned in the above group of patients. Creating a treatment schedule improving the quality of life and functioning of patients would be an important change in the standard of care in patients with LB.

\section{CONCLUSIONS}

1. In patients with LB, particularly those with neuroborreliosis, an increased frequency of depressive and neurotic disorders is observed.

2. Neurotic disorders, mainly adaptive, are most common in men with LB, while depressive disorders are more frequent in women.

3. In patients with neuroborreliosis, particularly in women, an increased frequency of cognitive deficits is observed.

\section{REFERENCES}

1. Paradowska-Stankiewicz I, Chrześcijańska I. Lyme borreliosis in Poland in 2011. Przegl Epidemiol. 2013; 67(2): 255-257.

2. Stanek G, Fingerle V, Hunfeld K-P, Jaulhac B, Kaiser R, Krause A, et al. Lyme borreliosis: Clinical case definitions for diagnosis and management in Europe. Clin Microbiol Infect. 2011; 17 (1): 69-79.

3. Flisiak R, Pancewicz S. [Diagnostics and treatment for Lyme borreliosis. Recommendations of PTEiLChZ.]. www.pteilchz.org.pl/data/ standardy/borelioza_z_lyme_2011.pdf(access: 2013.09.01) (in Polish).

4. Rudnik-Szałaj I, Popławska R, Zajkowska J, Szulc A, Pancewicz SA, Gudel I. [Mental disorders in Lyme disease.] Pol Merk Lek. 2001; 11(65): 460-462 (in Polish).

5. Fallon BA, Keilp JG, Corbera KM, Petkova E, Britton CB, Dwyer E et al. A randomized, placebo-controlled trial of repeated iv antibiotic therapy for Lyme encephalopathy. Neurology. 2008; 70: 992-1003.

6. Eikeland R, Ljostad U, Mygland A, Herlofson K, Lohaugen G.C. European neuroborreliosis: neuropsychological findings 30 months post-treatment. Eur J Neurol. 2012; 19: 480-487.

7. Bozzini S, Gambelli P, Boiocchi C, Schirinzi S, Falcone R, Buzzi P, et al. Coronary artery disease and depression: possible role of brain-derived neurotrophic factor and serotonin transporter gene polymorphisms. Int J Mol Med. 2009; 24(6): 813-818.

8. Szczepańska-Sadowska E, Cudnoch-Jedrzejewska A, Ufnal M, Zera T. Brain and cardiovascular diseases: common neurogenic background of cardiovascular, metabolic and inflammatory diseases. Physiol Pharmacol. 2010; 61(5): 509-521.

9. Talarowska M, Florkowski A, Gałecki P, Wysokiński A, Zboralski K. [Cognitive function and depression.] Psychiatr Pol. 2009; XLIII (1): 31-40 (in Polish).

10. Rymaszewska J, Adamowski T, Pawłowski T, Kiejna A. [Prevalence of mental disorders - a review of major epidemiological research]. Post Psychiatr Neurol. 2005; 14(3): 195-200 (in Polish).
11. Pawlak A, Krejca M, Janas-Kozik M, Krupka-Matuszczyk I, Rajewska J, Bochenek A. Ocena lęku i depresji w okresie okołooperacyjnym u pacjentów poddawanych rewaskularyzacji mięśnia sercowego. Psychiatr Pol. 20012; XLVI (1): 63-74 (in Polish).

12. Jakubowska-Winecka A, Włodarczyk D. Psychologiczne aspekty choroby i chorowania. In: Jakubowska-Winecka A, Włodarczyk D. Psychologia w praktyce medycznej. Warszawa, PZWL, 2007. p.94-125 (in Polish).

13. Corruble E, Guelfi JD. Pain complaints in depressed inpatients. Psychopathol. 2000; 33: 307-309.

14. Jaracz J, Rybakowski J. [Depression and pain: novel clinical, neurobiological and psychopharmacological data]. Psychiatr Pol. 2005; XXXIX (5): 937-950 (in Polish)

15. Borkowska A, Warwas I, Wiłkość M, Drożdż W. Neuropsychologiczna ocena dysfunkcji poznawczych w depresji po udarze mózgu. Psychiatria. 2007; 4(2): 39-44 (in Polish).

16. Holtzheimer PE, Mayberg HS. Neuropsychiatryczne aspekty zaburzeń nastroju. In: Yudofsky SC, Hales RE. Neuropsychiatria. Wrocław, Elsevier Urban \& Partner, 2010.p. 479-495.

17. Bidzan L, Dutczak B, Grabowski J. Neurobiologiczne podłoże związków między emocjami a funkcjami poznawczymi. Psychoterapia. 2012; 3(162): 5-15 (in Polish).

18. Stążka J, Szapietowska EM, Barańska E, Dudka P. Funkcjonowanie poznawcze osób z chorobą niedokrwienną serca leczonych kardiochirurgicznie - ocena przed i po zabiegu. Badania pilotażowe. Psychiatr Pol. 2012; XLVI(4): 539-552 (in Polish).

19. Pużyński S, Wciórka J. Klasyfikacja zaburzeń psychicznych i zaburzeń zachowania w ICD-1. Badawcze kryteria diagnostyczne. KrakówWarszawa, Vesalius, 1998 (in Polish).

20. Gugała M, Łojek E, Lipczyńska-Łojkowska W, Bochyńska W, Sawicka $\mathrm{B}$, Sienkiewicz-Jarosz H. [A review of neuropsychological methods for the assessment of mild cognitive impairment]. Post Psychiatr Neurol. 2007; 16(1): 81-85 (in Polish).

21. Folstein M, Folstein S, Mchugh P. Mini-Mental State: a practical method for grading the cognitive state of patiens for the clinician. J Psych Res. 1975; 12: 189-198.

22. Krzymiński S. Test Rysowania Zegara. Post Psych Neurol. 1995; 4(192): 21-30.

23. Beck AT, Ward CH, Mendelson M, Mock J, Erbaugh J. An inventory for measuring depression. Arch Gen Psychiatry. 1961; 4(6): 561-571.

24. Zajkowska JM, Hermanowska-Szpakowicz T. Nowe aspekty patogenetyczne boreliozy z Lyme. Przegl Epidemiol. 2002; 56 (1): 57-67 (in Polish).

25. Jarefors S, Janefjord CK, Forsberg P, Jenmalm C, Ekerfelt C. Decreased up-regulation of the interleukin-12R $\beta 2$-chain and interferon- $\gamma$ secretion and increased number of forkhead box P3-expressing cells in patients with a history of chronic Lyme borreliosis compared with asymptomatic Borrelia-exposed individuals. Clin Exp Immunol. 2006; 147: 18-27.

26. Jacek E, Fallon BA, Chandra A, Crow MK, Wormser GP, Aleadini A. Increased IFNa activity and differential antibody response in patients with a history of Lyme disease and persistent cognitive deficits. J Neuroimmunol. 2013; 255: 85-91.

27. Zajkowska J, Drozdowski W. Neuroborelioza - trudności diagnostyczne. Neurol Dypl. 2013; 8(1): 6-15 (in Polish).

28. Zajkowska JM, Kułakowska A, Tarasiuk J, Pancewicz SA, Drozdowski W. [Peripheral neuropathies in Lyme borreliosis]. Pol Merk Lek. 2010; XXIX(170): 115-118 (in Polish).

29. Zajkowska J, Hermanowska-Szpakowicz T, Pancewicz S. [Lyme borreliosis - guidelines for effective treatment]. Zakażenia. 2007; 4: 33-38 (in Polish).

30. DeLong AK, Blossom B, Maloney EL, Philips SE. Antibiotic retreatment of Lyme disease in patients with persistent symptoms: a biostatistical review of randomized, placebo-controlled, clinical trials. Contemp Clin Trials. 2012; 33:1132-1142.

31. Klempner MS, Baker PJ, Shapiro ED, Marques A, Dattwyler RJ, Halperin JJ, et al. Treatment trials for post-Lyme disease symptoms revisited. Am J Med. 2013; 126: 665-669.

32. Halperin JJ. Prolonged Lyme disease treatment. Neurology. 2008; 70: 986-987.

33. Cameron DJ. Clinical trials validate the severity of persistent Lyme disease symptoms. Med Hypotheses. 2009; 72: 153-156.

34. Halperin JJ, Baker P, Wormser GP. Common misconceptions about Lyme disease. Am J Med. 2013; article in press: http://dx.doi. org/10.1016/j.amjmed.2012.10.008

35. Hassett AL, Radvanski DC, Buyske S, Savage SV, Sigal LH. Psychiatric comorbidity and other psychological factors in patient with "Chronic Lyme Disease”. Am J Med. 2009; 122 (9): 843-850. 
36. Ogłodek E, Moś D, Araszkiewicz A. [Coexisting of borreliosis, depression and psoriasis]. Pol Merk Lek. 2010; XXVIII(163): 53-55 (in Polish).

37. Legatowicz-Koprowska M, Gziut AI, Walczak E, Gil RJ, Wagner T. [Borreliosis - simultaneous Lyme carditis and psychiatric disorders - case report]. Pol Merk Lek. 2008; XXIV(143): 433-435 (in Polish).

38. Helon B, Tłuczek TW, Buczyjan A, Adamczyk-Helon A, Wojnarowicz M. [Polymorhic mental disorders in the course of Lyme borreliosis case study]. Psychiatr Pol. 2009; XLIII (3): 353-361 (in Polish).

39. Stricker RB, Johnson L. Gender bias in chronic Lyme disease. J Womens Health. 2009; 18(10): 1717-1718.

40. Gustaw K, Beltowska K, Studzińska MM. Neurological and psychological symptoms after the severe acute neuroborreliosis. Ann Agric Environ Med. 2001; 8(1): 91-94.
41. Czupryna P, Kuśmierczyk J, Zajkowska JM, Ciemerych M, Kondrusik $\mathrm{M}$, Ciemerych A, et al. [Clinical forms of neuroborreliosis among hospitalized patients in the years 2000-2005]. Pol Merk Lek. 2007; 23(134): 103-106 (in Polish).

42. Rudnik I, Popławska r, Zajkowska J, Konarzewska B, Juchnowicz D, Pancewicz SA. [Mental problems in Lyme disease]. Pol Merk Lek. 2003; 15(86): 161-164 (in Polish).

43. Blanc F, GEBLY. [Neurologic and psychiatric manifestations of Lyme disease]. Med Mal Infect. 2007; 37(7-8): 435-445 (in French)

44. Westervelt HJ, McCaffrey RJ. Neuropsychological functioning in chronic Lyme disease. Neuropsychol Rev. 2002; 12(3): 153-177.

45. Juchnowicz D, Rudnik I, Czernikiewicz A, Zajkowska J, Pancewicz SA.[Mental disorders in the course of Lyme borreliosis and tick borne encephalitis]. Przegl Epidemiol. 2002; 56 (Suppl. 1): 37-50 (in Polish). 